\title{
FROM GEOCYCLES TO GENOMES AND BACK
}

\author{
Arpita Bose, Sebastian Kopf, and Dianne K. Newman
}

\section{2}

\section{INTRODUCTION}

A holy grail for environmental microbiologists is being able to predict the effects of any given microbial community on a particular environment. In an era of increasingly dramatic changes in global climate, this goal is becoming evermore important. It is now well accepted that microorganisms have had and continue to have a profound influence on shaping the chemistry of the Earth. It would thus be both intellectually satisfying and practically useful if we could enumerate the microbial players in a specific locale, and, knowing their metabolic potential and how they regulate their various metabolisms, make predictions about how their presence would shape the geochemistry of that locale as it evolves in time.

Despite significant progress that has been made in developing tools that would aid in this effort in the past decade, we are still very far from being able to accomplish this. This is due to many factors, including our limited

Arpita Bose, Department of Organismic and Evolutionary Biology, Harvard University, Cambridge, MA 02138. Sebastian Kopf, Division of Geological and Planetary Sciences, Caltech, Pasadena, CA 91125. Dianne K. Newman, Divisions of Biology and Geological and Planetary Sciences and Howard Hughes Medical Institute, Caltech, Pasadena, CA 91125. understanding of how microorganisms catalyze reactions that have a geochemical impact. Although we have become good at identifying which organisms inhabit a particular site, we seldom have a complete grasp of their metabolic potential and how their metabolisms are regulated, and we have an even poorer understanding of the stability and catalytic rates of their biogeochemically relevant enzymes. While impressive efforts have been made in describing the metabolic potential of specific microbial communities through large sequencing projects (e.g., metagenomic and metaproteomic reconstruction of microbial communities in acid-mine drainage systems [Wilmes et al., 2009; Allen and Banfield, 2005]), large gaps in our understanding remain.

In this chapter, we discuss ways a budding geomicrobiologist might embark on the quest to understand how microbial communities affect their environment and to predict how they will respond in the face of environmental change. To this end, we first introduce various methods geomicrobiologists have at their disposal to achieve this goal, including both traditional (nonmolecular) and molecular methods. Because this book concerns microbial interactions with metals, we have chosen to focus our discussion on iron-one of the most ubiquitous and biogeochemically relevant metals in 
the environment. We provide a brief review of the (bio)geochemistry of this element before concluding the final portion of this chapter with a description of Lake Matano, an iron-rich environment that is geochemically fascinating with respect to metal cycling. We use Lake Matano as a case study to illustrate how the approaches described in the first section might be applied to gain insight into the complex interplay between microorganisms and geochemistry in a specific context.

\section{METHODS AVAILABLE TO STUDY MICROBIAL COMMUNITIES}

Today, geomicrobiologists can take advantage of numerous approaches to ask questions about the roles microorganisms play in any given place. Although lately there has been great enthusiasm for molecular techniques, there is still great value in using traditional methods to characterize the contributions of microorganisms to a system. We begin with a description of the latter, because nonmolecular methods provide a foundation upon which to perform molecular studies.

\section{Nonmolecular Approaches}

Nonmolecular methods include techniques that involve studying microbial processes in the field (in situ) and those that involve studying a microbial process in the laboratory in microcosms or as isolated reactions (in vitro). Each approach has its advantages and disadvantages, as we will discuss.

\section{IN SITU METHODS}

The success of in situ methods depends heavily on having information about a given environment. For most commonly studied environments, such as lakes, rivers, wetlands, soils, and sediments, this would include geochemical parameters such as $\mathrm{pH}$, redox potential $\left(\mathrm{E}_{\mathrm{h}}\right)$, solute composition, carbon sources, and the availability of terminal electron acceptors in addition to geophysical properties relevant to the respective site (temperature, water depth and stratification, soil horizons, seasonality, wind regimen, etc.). This information sets the stage for use of the various in situ approaches described hereafter. One has to be aware, however, that in situ approaches in general have a few caveats. When studying a natural system, the role of microbes cannot always be based on "guilt by association," i.e., the presence of an organism at a site does not necessarily imply that it is mediating the geomicrobial process under question. In addition, microbes almost never occur in isolation. Either they form stable associations called "consortia" or they form transient associations where only one or a few members of an association are of interest and the rest just hitchhike their way into one's data. In addition, microbes undergo processes of dispersal, where they might be present in a sample only because they were in transit through the area being sampled.

To simplify in situ studies, workers have divided microbes found in a particular sample into (i) indigenous microbes, which are part of the normal microflora of the sample site and most likely are the geomicrobial agents being sought; (ii) adventitious microbes, which are transient passerby organisms that came into the sample site during dispersal; and (iii) contaminants, which are organisms introduced during sampling (Ehrlich and Newman, 2009b). Using some assumptions, we can classify the organisms present in a particular sample. Indigenous microbes will likely represent the numerically dominant species. The adventitious microbes, in many cases, might be incapable of growth under the prevailing conditions in the sample site, while contaminants might be recognized as organisms that are unlikely to be present in the setting where they were found (Ehrlich and Newman, 2009b).

In Situ Microscopy. Use of microscopy to study the role of geomicrobial organisms is a very simple means of studying microbial diversity at a given site. Visual examination followed by light microscopy is a traditional tool for observing microbes when they occur in 
abundance (Brock, 1978). Samples can either be directly visualized using light microscopy or after acquiring the microbes of interest, such as by the buried slide method. In this method a slide buried at a location of interest, for example, in the sediments of a lake or river bed, is retrieved after a few days of incubation and is washed and stained appropriately (Lawrence et al., 1997). Photosynthetic organisms are autofluorescent and thus can be visualized using fluorescence microscopy (Lawrence et al., 1997). Capillaries have also been used to draw up microbes, which were then studied under the microscope (Perfil'ev and Gabe, 1969). However, various forms of electron microscopy are also used in the field for less abundant organisms. These include transmission electron microscopy (TEM), scanning electron microscopy (SEM), and environmental SEM (Baker and Banfield, 1998; Ghiorse and Balkwill, 1983; Edwards, et al., 1999; Jannasch and Wirsen, 1981; Sieburth, 1975) (Fig. 1).

\section{In Situ Study of Geomicrobial Activity.} Radioisotopes can be used to study the biogeochemistry of certain substances to determine ongoing geomicrobial processes. They are especially useful because of the high sensitivity of their measurement, which allows the experimentalist to add very little radioactivity to a sample even for the detection of slow geomicrobial processes. For example, the globally relevant contribution of microbial communities to the sulfur cycle in the form of sulfate reduction and sulfide oxidation could be studied using either ${ }^{35} \mathrm{SO}_{4}{ }^{2-}$ or $\mathrm{H}^{35} \mathrm{~S}^{-}$. A small, predetermined amount of these chemicals could be added to a closed vessel at the depth from which the sample was originally taken (Ivanov, 1968). After incubation and the likely action of the geomicrobial organisms present in the sample, ${ }^{35} \mathrm{~S}^{2-}$ or ${ }^{35} \mathrm{SO}_{4}{ }^{2-}$ could be separated and quantified. This technique is also applicable for the investigation of microbial interactions with metals. In the case of manganese, for example, it can be used to determine the existence and extent of biological manganese oxidation. There are two approaches: the first method assumes that reduced $\mathrm{Mn}$ is insoluble and that the change in dissolved ${ }^{54} \mathrm{Mn}^{2+}$ after removal of the precipitated form is a measure of microbial ${ }^{54} \mathrm{Mn}^{2+}$ oxidation; the second method measures microbially assimilated ${ }^{54} \mathrm{Mn}$ using a filter-based assay (Burdige and Kepkay,
A.

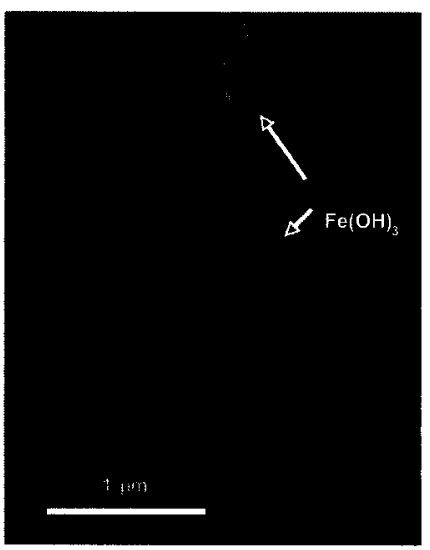

B.

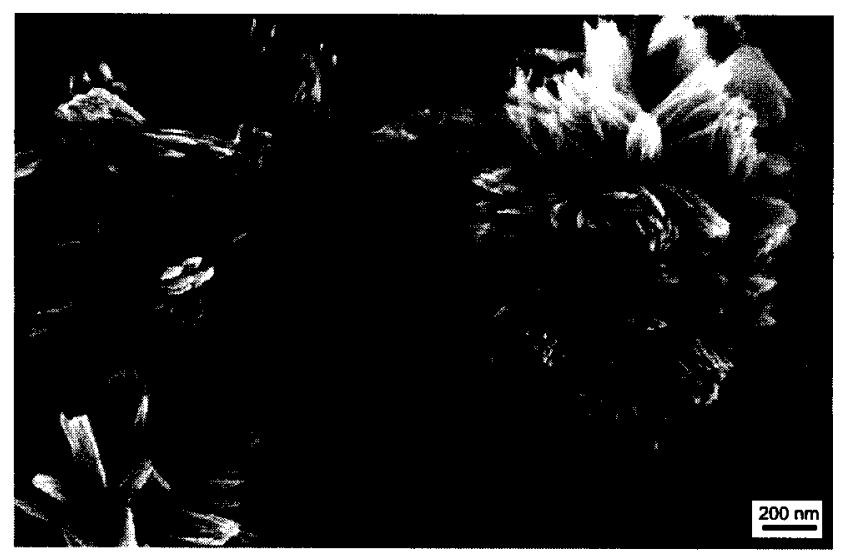

FIGURE 1 TEM and SEM of Rhodobacter strain SW2 grown photoferrotrophically. (A) TEM image of Rhodobacter strain SW2 grown photoferrotrophically for 5 days. Arrows indicate Fe(III) precipitates. Image previously published as Figure 4B in Adamczyk et al. (2003). (B) SEM of Rhodobacter strain SW2 grown photoferrotrophically for 4 weeks showing the crystalline, regularly shaped $\mathrm{Fe}$ (III) precipitates. 
the $16 \mathrm{~S}$ rRNA, has become the molecule of choice for phylogenetic identification (Stahl, 1997; Ward et al., 1990). This is because ribosomal RNA undergoes only minor sequence changes since it is part of the ribosome. Translation is an essential information pathway and extreme changes in the key machinery are rarely tolerated. This realization led Woese and coworkers to show that $16 \mathrm{~S}$ rRNA sequences from diverse organisms can be used for phylogenetic analysis (Olsen and Woese, 1993).

The 16S rRNA molecule has been tested for its rigor at assigning an unknown microbe a phylogenetic identity for nearly four decades, and has been proven robust. Many variations have been developed over the years to exploit $16 \mathrm{~S}$ rRNA. However, it should be noted that, while $16 \mathrm{~S}$ rRNA/DNA-based approaches might help assign an unknown organism an identity, in most cases this does not predict its metabolism (McArthur, 2006). This is because microorganisms are capable of diverse metabolisms, some of which have been moved around through horizontal gene transfer over evolutionary history, giving their genomes a fluidity that restricts the utility of $16 \mathrm{~S}$ rRNA/DNA to identification and phylogeny (Doolittle, 2000). In addition, other genes that are key players in other information pathways, such as transcription and DNA replication, can also add robustness to a phylogenetic assignment based on 16S rRNA/DNA (Olsen and Woese, 1993). Some organisms have multiple divergent $r m$ operons, i.e., ribosomal RNA encoding genes, which complicates identification of an unknown organism (Klappenbach et al., 2001). With these caveats in mind, $16 \mathrm{~S}$ rRNA/DNA still stands as one of the most commonly used biomolecules for identification and phylogenetic assignment.

In the following sections, we briefly summarize various culture-independent techniques that have become widely used in the past few decades. Such molecular methods can be applied to any environment of interest.

PCR-Based Methods. PCR-based methods allow identification of known and un- known organisms exploiting the ability of degenerate primers targeting $16 \mathrm{~S}$ rDNA to amplify divergent sequences (Guyer and Koshland, 1989). In practice, DNA is purified using commercial kits from any new isolate or complex microbial community. PCR and degenerate primers are used to amplify the $16 \mathrm{~S}$ rDNA, and sequenced directly for a pure culture or prepared into a PCR clone library followed by sequencing individual clones. This sequence is then compared with public databases such as GenBank (http://www.ncbi.nlm.nih.gov/Genbank/) or Ribosome Database Project (http://rdp.cme. msu.edu/). Because the 16S rDNA sequence for any new isolate or microbial community studied is submitted to these public databases, a quick comparison of the unknown sequence with this database allows geomicrobiologists to find the closest phylogenetic relative of the microbe under study (Color Plate 2). However, the level of sequence identity required to assign a microorganism at the species level is debated. Recent studies show that closely related $16 \mathrm{~S}$ rDNA sequences can be binned into clusters that represent bacterial taxa and are called an operational taxonomic unit (OTU). OTUs are defined as clusters with up to $2.5 \%$ sequence divergence in 16S rRNA (Hughes et al., 2001). This is based on the observed divergence seen within populations of known species (Stackebrandt and Goebel, 1994). Other workers have considered each 16S rRNA sequence type as a distinct OTU. However, no sequence-based OTU corresponds to the fundamental units of bacterial ecology; as pointed out earlier, $16 \mathrm{~S}$ rDNA and other single-gene-based approaches, in most cases, are limited to identification (Cohan, 2002; Staley, 2003).

An application of the PCR-based approach that gives insight into community composition is denaturing gradient gel electrophoresis. This method separates PCR products of similar size but differing sequence (Color Plate 2). $16 \mathrm{~S}$ rDNA can be amplified from a community and then hybridized with probes specific for a particular species being sought. In addition, individual bands of interest can be cut and eluted for reamplification followed by DNA 
sequencing to identify the associated microbe (Muyzer et al., 1993; Stahl, 1997; Ward et al., 1992, 1998). Another technique especially useful for comparing communities is terminal restriction fragment length polymorphism. One of the PCR primers used has a fluorescent label. DNA is amplified using PCR and digested with restriction enzymes. The DNA bands resulting from this digestion are separated according to size, and each fragment is detected by use of a laser detector that can detect the fluorescent label. Although a good measure of community structure, this method does not help in identification of individual organisms or OTUs (Clement et al., 1998; Dunbar et al., 2001; Liu et al., 1997). Finally, the use of DNA microarrays to catalogue microbial diversity is becoming increasingly popular. This method involves hybridization techniques using amplified DNA probed against a library of spotted DNA molecules on a glass slide that correspond to known organisms (Wu et al., 2006; Gentry et al., 2006).

FISH Methods. The large diversity of microbial $16 \mathrm{~S}$ rDNA sequences available allow us to design methods to use these known sequences to identify close relatives in uncharacterized communities. The approach that has exploited growing 16S rDNA sequences most is fluorescence in situ hybridization (FISH), although autoradiography-based approaches have also been used (Giovannoni et al., 1988; Amann et al., 1990, 1995). rRNA is an ideal biomolecule for identification of microbes for the following reasons: (i) Ribosomes are essential to survival of all forms of life including microbes. Under most physiological conditions microbes have thousands of ribosomal particles, which results in natural amplification of a signal. (ii) $16 \mathrm{~S}$ rDNA is conserved evolutionarily as discussed above. In addition, RNA molecules do not undergo evolution of the third (Wobble) base of each codon as happens in protein-coding genes. Thus, probes that span much larger regions of RNA can be designed, and probes can be constructed that detect much larger taxonomic units of Bacte- ria and Archaea. In practice, performing FISH is fairly straightforward (Color Plate 2); however, the success of FISH depends on many variables, which will be discussed later. First, the microbial cells in a given sample are fixed to stabilize cell morphology and permeabilize cells for later hybridization. Then, the cells are incubated with a labeled probe, at which point the probe enters the cell and hybridizes with the rRNA sequence; excess probe is washed off to reduce background. The sample can then be visualized by epifluorescence microscopy or the cells of interest can be sorted using flow cytometry. A database of successful and tested FISH probes is available on ProbeBase (http://www.microbial-ecology. net/probebase/) (Amann and Fuchs, 2008). One can also design a new FISH probe based on phylogenetic analysis from databases like SILVA (http://www.arb-silva.de/fish-probes/ probe-design/) (Amann and Fuchs, 2008). However, success of the new probe entails iterative testing and optimization, making it a tedious, time-consuming process. It also requires that a pure culture of the organism be tested, although techniques such as CloneFISH, which allows probes to be optimized without the need for pure cultures, can circumvent this issue (Amann and Fuchs, 2008). Various modifications of the basic FISH procedure have been developed to counter issues of failure to observe any/weak signal due to low ribosomal content or lack of active transcription. This includes catalyzed reported deposition FISH, a method that uses horseradish peroxidase-labeled oligonucleotide probes. The horseradish peroxidase catalyzes the deposition of tyramine molecules, which results in signal amplification (Pernthaler et al., 2002).

\section{Whole-Genome Sequence Approaches} (i.e., Phylogenomics). The caveats of using single-gene approaches to understand phylogeny ultimately affect our ability to identify organisms with certainty. Whole-genome sequencing is now affordable and routine in microbiology owing to the relatively small size of microbial genomes. This has led to the 
development of the concept of phylogenomics that uses all the genes in an organism to determine its phylogeny (for details, read Delsuc et al. [2005]). Availability of genomic data helps counter the effects due to too small sample size that phylogenetics faces by expanding the number of characters that can be used in phylogenetic analysis by orders of magnitude. Phylogenomics unlike phylogenetics involves the development of tools to analyze large sets of genomic data and makes phylogenetic inferences from it. What emerge from these studies are not only more robust phylogenetic trees, but also new species-like characters that are based on genome structure, such as rare genomic changes (Philippe and Laurent, 1998; Rokas and Holland, 2000).

\section{Caveats of Using DNA-Based Methods.} All the above-mentioned methods are DNA based; therefore, they all suffer from some basic problems. These include (i) the inability to access microbial cells that adhere to particles, (ii) the inability to lyse cells and isolate DNA, (iii) copurification of PCR inhibitors that affect downstream applications, (iv) shearing of DNA, (v) PCR bias, and (vi) PCR-based errors (Ehrlich and Newman, 2009a). Although the recognition of these problems leads to the development of better technology, another way to circumvent such issues is to use other approaches like those mentioned below. Information gained from each approach can then converge into a unified and reliable data set.

\section{WHAT ARE THEY DOING?}

When analyzing a particular environment for microbial activity, the first step is often to determine which organisms are present in that niche ("Who is there?"). However, owing to the concepts of indigenous, adventitious, and contaminant organisms introduced earlier, the presence of an organism does not always mean it is playing a direct role in a specific geomicrobial process of interest. The nonmolecular in situ and in vitro methods described earlier can shed light on the specific role of microbes present in a given environment; in addition, a number of molecular methods can help answer the "What are they doing?" question with finer resolution. Such methods can be applied to single cells or microbial communities.

Single-Cell Approaches. The general principle of single-cell methods combines identification of single cells with separation of the desired population of these cells, and then determining their particular characteristics (Color Plate 3).

FISH-MAR. This was one of the first single-cell approaches developed to understand microbial communities. It involves using radiolabeled substrates and monitoring their incorporation into macromolecules of a desired set of organisms that are identified in parallel with FISH approaches. The use of radio-labeled substrates makes FISH-microautoradiography (FISH-MAR) very sensitive such that short incubations suffice. However, a disadvantage is that radio-labeled compounds not incorporated into macromolecules are lost during sample preparation for FISH analysis. Thus, the nature of the metabolic products is never obvious (Lee et al., 1999; Ouverney and Fuhrman, 1999). FISH-MAR also has a number of other limitations. (i) It requires active growth of the microbial population under study, (ii) it requires prior knowledge about the kind of organisms that are present in a given sample, (iii) only a limited number of populations can be visualized simultaneously using FISH owing to the requirement for distinct fluorophores, (iv) FISH analysis might not be possible for some microbes, and (v) the desired radio-labeled substrate is unavailable (Ehrlich and Newman, 2009a). The techniques described below help circumvent some of these issues.

FISH-SIMS. This method combines FISHbased identification of an organism followed by analysis of the stable isotopic composition of the desired cells by use of an ion microprobe. The advantage of secondary ion mass spectrometry (SIMS)-based approaches is the ability to analyze the surface of a microbe or 
microbial assembly to resolve the spatial distribution of small isotopic differences. This powerful technique thus allows spatial tracing of isotopic signals (whether from naturally occurring signatures such as isotopically light methane or labeled ${ }^{13} \mathrm{C}$ and ${ }^{15} \mathrm{~N}$ incubations) as they are assimilated, incorporated, and propagated by the different microbial populations fluorescently tagged with FISH. FISH-SIMS has been, for example, very successfully used in the past decade to investigate consortia of methane-oxidizing archaea with sulfate-reducing bacteria responsible for anaerobic methane oxidation in numerous natural environments (Orphan et al., 2001; Pernthaler et al., 2008).

Magneto-FISH. Another modification of FISH makes use of magnetic beads attached to antibodies specific for the fluorophore used in the catalyzed reported deposition FISH technique. This allows immunoseparation of a desired phylogenetic group of microbes. The separated cells can then be used to isolate DNA for metagenomic analysis. It is especially useful in isolating microbial consortia (Pernthaler et al., 2008).

Single-Cell PCR. Recent advances in single-cell PCR approaches have enhanced our ability to assess single cells of microorganisms while simultaneously linking these capabilities to their phylogeny. Microfluidic digital PCR allows amplification of $16 \mathrm{~S}$ rDNA sequences along with other genes that serve as markers for a specific metabolic capability. This technique is therefore unbiased with respect to transcriptional levels and protein content, which are major limitations of FISH-based approaches (Ottesen et al., 2006). Singlecell PCR, combined with single-cell wholegenome sequencing, is a powerful tool and paves the road to single-cell phylogenomics.

Community Approaches. Although single-cell approaches are useful to understand the metabolic capabilities of individual cells, how these metabolisms combine to give rise to an observed geochemical profile entails studying a whole community. A few of such com- munity-based methods are discussed below. However, newer methods that combine the single-cell approaches with the communitybased approaches are becoming increasingly popular.

SIP. Stable isotope probing (SIP) involves tracking stable isotopes from particular substrates into components of microbial cells that provide phylogenetic information (biomarkers). This process has primarily been used to identify the microorganisms involved in specific biogeochemical transformations that are important in global elemental cycling. The first instance when SIP was used was to study incorporation of ${ }^{13} \mathrm{C}$ into polar lipid-derived fatty acids (PLFAs) (Petsch et al., 2003). However, the phylogenetic resolution offered by PLFAs is much lower in comparison with $16 \mathrm{~S}$ rRNA/DNA-based methods. Thus, DNASIP and RNA-SIP were devised.

DNA labeled with stable isotopes can be isolated from mixed microbial communities, based on the increase in buoyant density associated with isotopic enrichment. Density centrifugation in $\mathrm{CsCl}$ gradients can then be used to separate labeled from unlabeled DNA, and 16S rDNA clone libraries constructed from labeled DNA can be sequenced to obtain the identity of organisms assimilating the labeled substrate. Although DNA-SIP offers phylogenetic resolution superior to PLFA-SIP, it requires a high level of isotopic enrichment. For instance, DNA must contain at least 15 to $20 \%{ }^{13} \mathrm{C}$ before it can be isolated on the basis of buoyant density (Radajewski et al., 2000). DNA synthesis is related to replication, but bacterial replication in most environments is slow. Therefore, the incorporation of stable isotopes into DNA may not be efficient for DNA-SIP to be applied. The use of RNA as a biomarker in SIP helps circumvent this drawback of DNA-SIP. Transcription occurs with a much higher turnover rate and so the incorporation of the stable isotope is much higher in RNASIP. Labeled RNA can be isolated by density centrifugation, on cesium trifluoroacetate gradients. Followed by reverse transcription, 
PCR and sequencing then provide the phylogenetic information desired (Dumont and Murrell, 2005; Whiteley et al., 2006). The advantage of SIP methods is the ability to identify hitherto unknown organisms involved in biogeochemical processes.

Isotope Array. Isotope array methods combine the utility of DNA microarrays with the benefits of stable isotope probing. RNA-SIP is performed, and the isolated RNA is then labeled with a fluorescent dye. This labeled RNA is then used to probe a $16 \mathrm{~S}$ rRNA microarray of predetermined microbes. Isotope arrays unfortunately are limited in application because of the requirement to have prior knowledge about the organisms being sought (Hesselsoe et al., 2009; Adamczyk et al., 2003).

Metagenomics, Metatranscriptomics, and Metaproteomics. Metagenomic analysis ensues the direct isolation of genomic DNA from an environment and thus circumvents culturing the organisms under study. Subsequently cloning this DNA into a cultured organism (such as Escherichia coli) confines it for study and preservation (Riesenfeld et al., 2004). Metagenomics has seen numerous advances such that it is even possible to reconstruct whole genomes of uncultured organisms with some certainty (Woyke et al., 2009). It has also provided new genes that have later been pursued using classical genetic and biochemical tools and shown to encode novel enzymes (Hoff et al., 2008). However, metagenomics alone does not directly tell us the metabolic role a particular organism (or gene) might play in a given environment, because DNA only stores information. The transcription, translation, and regulation of the gene products allow organisms to affect their surroundings, resulting in a complex geomicrobial process. Despite its limitations, metagenomics can offer powerful initial insights into the possible microbes and microbial processes that might occur in a given environment.

Metatranscriptomics helps understand which genes in a community are transcribed at any given time. Thus, unlike metagenomics, direct inferences can be drawn about which genes are important under the condition being assessed. Like metagenomics, metatranscriptomics (or environmental transcriptomics) involves random sequencing of microbial community mRNA. Because no primers or probes are required for direct sequencing, there is no need to anticipate important genes a priori and transcripts from microbial assemblages are sequenced without bias. Furthermore, highly similar sequences, which might cross-hybridize on a microarray, can be distinguished by having a unique sequence (Warnecke and Hess, 2009; Shi et al., 2009). Experimental metatranscriptomics involves assessing changes in transcription in a particular environment and is a powerful tool for understanding the timing and regulation of complex microbial processes within communities and consortia, as well as microbial dexterity in response to changing conditions (Warnecke and Hess, 2009). Community expression profiling via direct sequencing saves data obtained from individual metatranscriptomic studies and added to community databases. These include CAMERA (http://camera.calit2.net/), MG-RAST(http://metagenomics.nmpdr.org/), or IMG/M (http://img.jgi.doe.gov/cgibin/ $\mathrm{m} /$ main.cgi).

Metaproteomics, the identification of proteins isolated from a given environment is a recent development in environmental $\mathrm{mi}$ crobiology due to advances in sophisticated protein isolation and mass spectrometric techniques (for recent reviews, see Wilmes et al. [2008], Maron et al. [2007], Klaassens et al. [2007], and Wilmes and Bond [2006]). Metaproteomics has a great advantage over metagenomics and metatranscriptomics because it measures the actual molecular catalysts (i.e., enzymes) that mediate geochemical transformations. Thus, it circumvents the concern that gene expression is not an accurate predictor of the activity of a given gene product in any given environment.

\section{HOW ARE THEY DOING IT?}

Knowledge about which organisms are present in an environment, along with information 
about the metabolic reactions they perform can prompt questions such as: How do these organisms do what they do? What are the genes responsible? Do these genes resemble other known genes? If these genes encode enzymes, what is their mechanism and how are their rates of catalytic activity affected by relevant environmental variables? Where are the products of these genes located in the cell? What other molecular factors are required for their assembly? How are these genes or gene products regulated? Only by answering these questions can geomicrobiologists achieve a deeper level of understanding over the variables that control microbial activities. Such depth of knowledge, ultimately, is necessary for being able to predict how microbial communities will respond to and, in turn, modify an environment as it changes over time. To acquire this information, geomicrobiologists can draw on a wealth of tools from the fields of classical genetics, biochemistry, and cell biology.

Genetics. Classical genetics is extremely powerful and techniques in microbial genetics have been honed immensely over decades. Genetics has also kept abreast with advances in molecular biology such that molecular genetics is now commonplace. Through tools of both random and directed mutagenesis, scientists can identify genes that are linked to a particular metabolic capability (Maloy and Cronan, 1994). The prerequisites for performing random mutagenesis on an organism are (i) the existence of a pure or partially pure culture, (ii) the ability of the organism to form colonies on solidified media, (iii) the ability to transfer DNA into the isolated organism, (iv) the ability to assay the phenotype being sought, and (v) the ability of one or more plasmids to stably replicate in the native host for complementation experiments. If all these requirements are met, random mutagenesis can be performed using various established protocols (Color Plate 4) (Salyers et al., 2000). The use of targeted gene deletion requires, in addition to the requirements for random mutagenesis, the knowledge of the genome sequence or at least the region surrounding the locus to be deleted. Two methods, both based on homologous recombination, are generally used: (i) insertional inactivation and (ii) markerless deletion (Color Plate 4) (Rother and Metcalf, 2005; Guss et al., 2005; Pritchett et al., 2004).

In case an organism does not fulfill the requirements listed above, the method of heterologous complementation can be applied using a closely related genetically tractable organism. DNA isolated from the organism under study is cloned into plasmids that replicate in the host organism. The host organism is then tested for gain of the activity that is being sought (Color Plate 5). Many examples exist where this approach has been successfully applied (Croal et al., 2007; Beja et al., 2000; Martinez et al., 2007).

Bioinformatics and Subsequent Studies. The identification of a genetic locus that confers a certain metabolic capability to an organism leads to the question of what these genes encode. Standard bioinformatics tools provided as public online user interfaces are available on the World Wide Web. NCBI blast (http://blast. ncbi.nlm.nih.gov/Blast.cgi), a basic alignment search tool, helps find the closest homologs of an unknown gene from available sequences submitted to GenBank. Other websites such as Expert Protein Analysis System (http:// www.expasy.ch/) and EMBL-EBI servers (http://www.ebi.ac.uk/Tools/) provide numerous tools that allow users to determine the likely protein or RNA domains and motifs present in a DNA sequence. Although bioinformatics points to the putative role of a protein or RNA, the actual role of a biomolecule needs to be determined using experimental methods; for instance, the biochemical analysis of proteins or the study of function of small RNAs. Localization of proteins can also be studied using methods developed by cell biologists involving the use of sophisticated microscopic tools in conjunction with fluorescent reporters (green fluorescent protein and its derivatives) (Valdivia et al., 2006). Gene regulation studies can also be performed using quantitative reverse 
transcription-PCR and classical reporter gene fusions (Seeber and Boothroyd, 1996; Miller and Hershberger, 1984).

\section{THE (BIO)GEOCHEMISTRY OF IRON}

\section{Iron at the Earth's Surface}

Iron is the most abundant element on Earth, contributing $32 \%$ by weight to the bulk composition of our planet (Morgan and Anders, 1980). A large portion of the iron is concentrated in the inner core, but the element still constitutes a remarkable $5 \%$ of the Earth's crust on average, exceeded in crustal abundance only by oxygen, silicon, and aluminum (Rankama and Georg Sahama, 1950). The chemical reactivity of iron and its role as one of the most important reduction-oxidation (redox) active elements implicate iron in a myriad of highly relevant geochemical as well as biochemical transformations.

Igneous rocks rich in iron-bearing mafic minerals, such as olivine and pyroxene, are the primary source of iron to the Earth's crust and surface environment. The (bio)geochemical cycling of iron at the Earth's surface starts with the mobilization of iron during erosion and weathering of exposed igneous rock, as well as during hydrothermal circulation of seawater at oceanic spreading centers (the sources). Subduction of iron-bearing oceanic crust and seafloor sediments ultimately returns iron to the mantle (the sink) where the rocks can melt, form a magma, and reenter the igneous rock cycle. Once in a mobile phase as a particulate mineral or dissolved ion, many physicochemical processes can occur, altering properties such as solubility and chemical speciation (Ussher et al., 2004). Iron is distributed throughout the hydrosphere by riverine and marine fluxes, transported in the atmosphere in aerosols and dust particles, and spread throughout the lithosphere by sedimentary processes, mineral precipitation, and diagenesis, making up a large proportion of soils and sedimentary rocks from where it can be remobilized. Its complex biogeochemical cycle affects not only its own distribution in the lithosphere, hydrosphere, atmosphere, and biosphere, but also the distribution and processes of other important element cycles such as those of carbon, nitrogen, and sulfur.

Iron is most commonly observed in its ferrous (oxidation state +2 ) or ferric (oxidation state +3 ) form. Reducing conditions in the mantle and deep crust make the ferrous form dominant in magma and fresh igneous rock, but ferric iron is stable at present oxic atmospheric conditions, making +3 the most common oxidation state in surface environments. However, the dynamic and variable chemistry of many surface environments sometimes allows for considerable amounts of ferrous iron and co-occurrence of both oxidation states. The following chemical reactions exemplify two typical redox transformations of iron: (I) the oxidation of $\mathrm{Fe}^{2+}$ by molecular oxygen to form a simple, insoluble $\mathrm{Fe}^{3+}$ hydroxide and (II) the reduction of $\mathrm{Fe}^{3+}$ by excess hydrogen sulfide, partially precipitating as an iron sulfide mineral (pyrite). Both reactions are relevant redox pathways in natural environments.

$$
4 \mathrm{Fe}^{2+}+\mathrm{O}_{2}+10 \mathrm{H}_{2} \mathrm{O} \rightarrow 4 \mathrm{Fe}(\mathrm{OH})_{3}(\mathrm{~s})+8 \mathrm{H}^{+}
$$

$$
2 \mathrm{Fe}^{3+}+2 \mathrm{H}_{2} \mathrm{~S} \rightarrow 2 \mathrm{FeS}_{2}(\mathrm{~s})+\mathrm{Fe}^{2+}+4 \mathrm{H}^{+}
$$

The solubility and chemical behavior of iron in aqueous environments is heavily influenced by its speciation, that is, the actual form in which it is present in solution. Besides the oxidation state of the element, speciation depends largely on acidity/alkalinity of the environment $(\mathrm{pH})$ and the availability of ligands. Ferric iron is generally much less soluble than ferrous iron, especially at circumneutral $\mathrm{pH}$, although strong ligands can improve its stability in solution. Ferric iron in marine environments, for example, has been found to be $>99 \%$ complexed by strong organic ligands (Ussher et al., 2004). The solubility of the ions is ultimately limited by the stability of various minerals, for example, siderite and pyrite for $\mathrm{Fe}^{2+}$, and (oxy)hydroxides and oxides like ferrihydrite, goethite, and hematite for $\mathrm{Fe}^{3+}$.

The biogeochemical cycling of iron strongly influences other element cycles by means of 
mineral formation and dissolution, coupling of redox cycles, as well as enzymatic catalysis. The distribution and transformation of iron in the Earth's surface environment have a particularly noteworthy impact on the previously mentioned, globally important cycling of nitrogen, sulfur, and carbon (illustrated schematically in Fig. 2). While iron and nitrogen redox cycling is coupled directly in the microbial process of anaerobic respiration of ferrous iron with nitrate, iron impacts the nitrogen cycle most pervasively in its role in enzymatic catalysis (Weber et al., 2006). A wide variety of metalloproteins and cofactors incorporate iron in their active sites, and virtually all processes of the microbially mediated cycling of nitrogen (nitrogen assimilation, fixation, denitrification, nitrification) require small amounts of iron for this purpose. Many surface environments are rarely limited by iron availability, but the low concentrations of iron in ocean waters can crucially affect the productivity and ecology of the oceans by limiting nitrogen fixation (Falkowski et al., 1998; Morel, 2003).

The sulfur and iron cycles are closely linked through the mutually controlled formation of iron-sulfur minerals, such as the aforementioned pyrite, and through the reductive interaction of sulfide species with ferric iron (Canfield et al., 1992). The two cycles are, however, most intimately intertwined in their prominent role as iron-sulfur (FeS) clusters in a variety of metalloproteins and cofactors involved in electron transfer reactions that impact a variety of other element cycles.

The biogeochemical cycling of iron is linked to the carbon cycle in various direct and indirect ways. Direct links include the formation

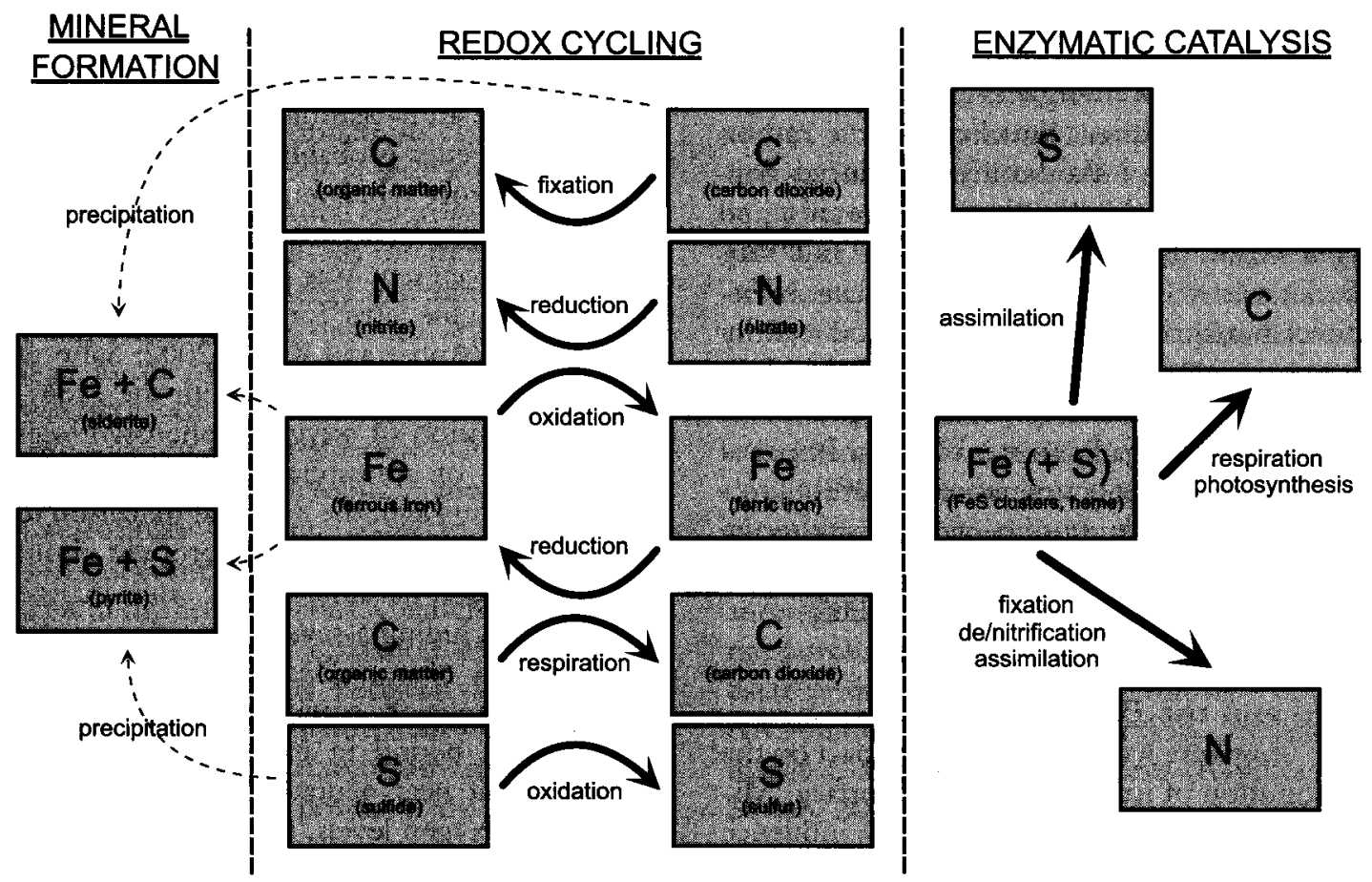

FIGURE 2 Simplified illustration of the coupling of the biogeochemical cycling of iron with the carbon, nitrogen, and sulfur cycles. Shown are interactions of the element cycles during mineral formation and dissolution (left column: arrows indicate precipitation, parentheses provide examples of mineral species), redox cycling (center column: arrows illustrate redox transformations coupled to iron oxidation/reduction, parentheses provide examples of the reduced and oxidized species involved), and enzymatic catalysis (right column: arrows indicate examples of iron-dependent metabolic processes for sulfur, carbon, and nitrogen, respectively). 
of the iron-carbonate mineral siderite as well as the coupling of redox cycling in phototrophic iron oxidation (where ferrous iron is used as a source of electrons to fix carbon) and dissimilatory iron reduction (where organic substrates are respired using ferric iron as the terminal electron acceptor). In its catalytic function in enzymes, iron is central to redox metabolism (Fraústo da Silva and Williams, 2001). It plays an active role, for example, in many enzymes involved in the electron transfer reactions of both respiration and photosynthesis, and furthermore influences the carbon cycle indirectly through its effects on the nitrogen cycle.

Finally, the interaction of iron with the carbon and sulfur cycle has played an important role in the accumulation of atmospheric oxygen throughout Earth's history. The accumulation of oxygen at the Earth's surface is largely controlled by the direct burial of organic carbon and the indirect burial of the reducing power from organic carbon in the form of pyrite. The direct burial of organic carbon prevents some of the biomass produced during oxygenic photosynthesis to be respired again with the produced oxygen, and thus frees some of the oxygen to accumulate. In indirect burial, the organic matter produced by oxygenic photosynthesis drives sulfate reduction and iron reduction, producing pyrite and oxidizing the organic matter to $\mathrm{CO}_{2}$. Burial of pyrite through the couplings of the carbon, sulfur, and iron cycle thus liberates oxygen to the atmosphere (Garrels and Lerman, 1981; Berner and Maasch, 1996; Canfield et al., 2005).

\section{Iron and the Biosphere}

The biosphere has a tremendous impact on the distribution of iron at the Earth's surface. Microorganisms, in particular, heavily influence the geochemical cycling of iron in various ways. Most organisms assimilate small amounts of iron to satisfy their nutritional demands for the element. In the process, they heavily influence the mobilization of iron from rocks, soils, and sediments and alter the speciation of iron in aqueous environments. This is a result of both active and passive microbial activities through the deliberate production of molecules for iron acquisition and by action of common metabolic products such as organic acids, respectively. Many microorganisms can catalyze the oxidation or reduction of iron both actively by metabolizing iron to generate energy for growth and passively, e.g., by influencing the chemistry of their immediate surroundings or providing catalytic surfaces for mineral formation.

\section{IRON AS A NUTRIENT}

Iron is an essential nutrient for the survival, growth, and reproduction of almost all forms of life. As a key catalyst in several enzymatic electron transfer reactions, iron is required by most organisms for vital cellular processes ranging from respiration to photosynthesis, nitrogen fixation, and the oxidative stress response (Fraústo da Silva and Williams, 2001). Many of the iron-bearing enzymes involved in these processes probably evolved at a time in Earth's history when ferrous iron was abundant in the world's oceans because the Earth's surface environment was still anoxic and the much less soluble ferric form of iron could not yet stabilize (Anbar and Knoll, 2002; Saito et al., 2003; Glass et al., 2009). With the evolutionary invention of oxygenic photosynthesis and the rise of atmospheric oxygen around 2.4 billion years ago, the eventual oxidation of the Earth's surface and oceans brought about drastic changes in atmospheric and marine chemistry including a severe limitation in the bioavailability of iron. Despite being the most abundant transition metal in the biosphere, most iron is bound in insoluble oxides and hydroxides at near-neutral $\mathrm{pH}$ at present atmospheric oxygen levels. It is thus hardly surprising that the biosphere has evolved many elegant ways to influence the cycling of iron to allow for assimilation. In response to the scarcity of bioavailable iron in many natural environments, many microorganisms have, for example, evolved the ability to synthesize 
potent chelating agents to aid in iron acquisition. The fascinating and complex process of mobilization and acquisition of iron by these iron-specific chelators, commonly known as siderophores, is discussed in detail by Kraemer (2004) and Kraemer et al. (2005).

\section{IRON AS AN ENERGY SOURCE}

All nonphototrophic organisms take advantage of concentrations of oxidizable and reducible species that are far from those demanded by thermodynamic redox equilibria and kinetically too slow to proceed on their own. This is what happens in respiration, where organic matter (highly reduced) and molecular oxygen (highly oxidized) are out of thermodynamic equilibrium, but the kinetics of abiotic combustion at standard conditions are so slow that they do not just recombine spontaneously. Microorganisms gain energy by catalyzing such redox reactions in a controlled manner to restore thermodynamic equilibrium. Microbially mediated transformations of iron are often much faster than their abiotic equivalents and are ubiquitous in natural environments. A wide variety of physiologically different prokaryotes can use iron for energy generation, either by using ferric iron in dissimilatory iron reduction as an oxidant to respire more reduced substrates, or by metabolizing ferrous iron in dissimilatory iron oxidation with a stronger oxidant. These microbially mediated redox transformations often occur in combination and can contribute to extensive (re-)cycling of iron in the environment. Canfield et al. (1993) estimated repeated oxidation and reduction in coastal sediments between 100 and 300 times before ultimate burial into the sediment. A good review of microbially mediated iron redox processes is provided by Kappler and Straub (2005).

To gain energy from the oxidation of ferrous iron with molecular oxygen in aerobic environments, microorganisms have to compete with abiotic oxidation. At circumneutral $\mathrm{pH}$, the chemical reaction proceeds within minutes and neutrophilic iron oxidizers have to cata- lyze iron oxidation extremely fast (Stumm and Morgan, 1995). Emerson and Weiss (2004) provide a detailed description of aerobic iron oxidation at neutral $\mathrm{pH}$. At more acidic conditions ( $\mathrm{pH}<5$ ), the stability of ferrous iron increases and chemical oxidation proceeds much more slowly, allowing microorganisms to compete more easily. However, the energy gained from oxidation decreases with $\mathrm{pH}$, and much larger quantities of iron need to be oxidized to meet cellular energy requirements. A variety of acidophilic iron-oxidizing bacteria from all across the proteobacteria (most prominently Acidithiobacillus ferrooxidans), nitrospira, firmicutes, and acidobacteria, as well as several archaeal strains from lineages from the Thermoplasmatales and Sulfolobales (e.g., Edwards et al. [2000]) have been identified, in particular, in acid mine drainage environments where acidic conditions prevail and sufficient quantities of ferrous iron, mostly in the form of pyrite, are available (see Baker and Banfield [2003] for a review). In addition to aerobic iron oxidizers, several microorganisms have been discovered that can oxidize ferrous iron anaerobically by respiring nitrate at neutral $\mathrm{pH}$ (see Weber et al. [2006]). Although considered a possible form of anoxic phototrophic metabolism for a long time, the so-called photoferrotrophs, bacteria that grow photosynthetically with ferrous iron as their sole source of reducing power, were only discovered in the early 1990 s by Widdel et al. (1993). In the past decade, several cultures of iron-oxidizing phototrophic bacteria from all three major phylogenetic lineages of anoxygenic phototrophs (purple sulfur bacteria, purple nonsulfur bacteria, and green sulfur bacteria) have been isolated from such diverse environments as iron-rich springs, freshwater marshes, and marine sediments (Kappler and Straub, 2005).

Instead of harnessing energy from existing thermodynamic disequilibria, fixation of solar energy by photosynthesis actually creates new thermodynamic gradients that can be harnessed to support cell growth. As such, photoferrotrophy is fundamentally different from all other microbial interactions with the iron 
cycle. It is, in fact, the only microbial process that can change the redox state of iron species in natural environments against the thermodynamic resting state. As such, photoferrotrophy holds the power to drive redox cycling on the Earth's surface independent of oxygenic photosynthesis. Although such an isolated occurrence of photoferrotrophy, completely decoupled from oxygenic photosynthesis, is unlikely to occur today owing to the ubiquity and evolutionary success of oxygenic photosynthesis, it might still constitute an important contribution to primary productivity and the generation of oxidants in shallow sediments and iron-rich microenvironments. Furthermore, assuming an early evolution of anoxygenic photosynthesis preceding the evolution of cyanobacteria and oxygenic photosynthesis, photoferrotrophs could have been the dominant primary producers in a ferrous iron-rich Archean ecosystem.

This last assertion is of particular interest in the context of Earth's evolution because of the occurrence of massive iron-rich sedimentary deposits known as banded iron formations (BIFs) from a time in Earth's history when dissolved ferrous iron was abundant in the Earth's oceans but molecular oxygen was still extremely scarce. Photochemical oxidation of ferrous iron by UV radiation was considered a possible mechanism, but recent findings have cast doubt on the efficiency of such a process for the deposition of BIF, and it is generally believed that chemical or microbially mediated oxidation of ferrous iron by molecular oxygen from early oxygenic photosynthesis played the main role in BIF formation (Konhauser et al., 2007). More recently, however, the possibility of photoferrotrophic iron oxidation has been advanced as an alternative or complementary mechanism for banded iron formation (e.g., Kappler et al. [2005] and Posth et al. [2008]). A good review on the extent and significance of several major banded iron formations is provided by Beukes and Gutzmer (2008).

The ability to use the product of ferrous iron oxidation, ferric iron, as a terminal electron acceptor is widespread; numerous bacteria and archaea capable of dissimilatory ferric iron reduction at circumneutral and acidic $\mathrm{pH}$ have been isolated in the past decade. The environmentally most important inorganic reductant for ferric iron is hydrogen sulfide, which constitutes a kinetically competitive abiotic pathway and commonly contributes to iron cycling, especially when produced in large quantities during microbial sulfate reduction. A variety of organic and inorganic substrates can be respired and some organic substrates fermented with ferric iron depending on the strain and mineral form of the iron available, although not all iron-reducing bacteria can grow with iron as the sole electron sink. It is unclear whether this occurs because of an inability to gain energy from the process or whether the energy gained is insufficient to support growth but could still be important for survival. The ubiquity of iron minerals in sediments and breadth of substrate flexibility makes dissimilatory iron reduction an important metabolic pathway for the anaerobic mineralization of organic matter, especially in environments where sulfate and nitrate are unavailable terminal electron acceptors. However, a challenge of this metabolism is that organisms have to use an insoluble electron acceptor and cope with the difficulty of either solubilizing the iron mineral or transferring electrons from the cell to the mineral surface. Three different strategies seem to have evolved in response to this problem, although their distribution in natural environments remains inconclusive: (i) physical contact with the mineral surface for direct electron transfer, (ii) synthesis of iron chelators to solubilize ferric iron, and (iii) synthesis of redox-active molecules to shuttle electrons to the mineral surface. See Lovley et al. (2004) for a comprehensive review.

Because the majority of ferrous iron-oxidizing and ferric iron-reducing prokaryotes were isolated during the past decade, it is hardly surprising that our knowledge of these microorganisms, their metabolism, and especially their contribution to the biogeochemical cycling of iron is still in its infancy (Kappler and Straub, 2005). This is particularly true for the 
most recently discovered group of anoxygenic phototrophic iron oxidizers whose metabolic potential and place in microbial ecosystems has only recently started to be investigated and fully appreciated.

\section{FROM GEOCYCLES TO GENOMES AND BACK: LAKE MATANO AS A CASE STUDY}

A recent study of the iron-rich Lake Matano in Indonesia by Crowe et al. (2008a) provides an interesting case study for a joint geochemical and microbiological effort to investigate the roles that microorganisms play in shaping the geochemistry of this environment. In this final section, we describe what is known about Lake Matano and discuss how the traditional and molecular microbiological approaches described above may be used to gain insight into how microorganisms affect the biogeochemical cycling of iron and other elements in this environment.

Lake Matano, a part of the Malili Lakes system of Indonesia, is among the ten deepest lakes on Earth. It is estimated to be between one and four million years old (Brooks, 1950). It has relatively stable physical characteristics leading to species endemism, which has been studied in this lake by numerous workers (Sabo, 2006; Myers et al., 2000). Its unique iron geochemistry makes the lake a particularly interesting analogue for the chemistry of the oceans on early Earth (Crowe et al., 2008a), which differed markedly from modern environments. As discussed earlier, the lack of oxygen, presence of low concentrations of sulfide, along with the abundance of ferrous iron have implicated microbially mediated $\mathrm{Fe}$ (II) oxidation as a possible mechanism for the formation of extensive BIFs in the Archean ocean (Canfield et al., 2000, 2005; Isley and Abbott, 1999). Because Lake Matano's geochemistry may resemble the composition of ancient oceans (Crowe et al., $2008 \mathrm{a}$ ), it provides an opportunity to study the closely linked biogeochemical cycles of iron, carbon, and sulfur in an environment that can be characterized both geochemically and microbiologically (Crowe et al., 2008b). As discussed in detail below, numerous interesting observations have emerged from the study of the geochemistry of this lake and point to the likelihood of novel microbial metabolisms working within it that actively shape the geochemistry of the lake (Crowe, 2008; Crowe et al., 2008b).

Lake Matano is a tropical lake and therefore shows many typical characteristics of lake systems at low latitudes, such as higher annual irradiance, lack of seasonal variation, and high amounts of $\mathrm{Fe}$ and $\mathrm{Mn}$ hydroxides supplied from extensive weathering of iron-rich country rock in the drainage basin (Crowe et al., $2008 \mathrm{~b}$ ). The lack of large temperature fluctuations can facilitate poor mixing of the different layers of water, often leading to seasonal stratification, i.e., a separation of the water column into stable layers of differing water densities because of temperature and salinity differences. In the case of Lake Matano, the great depth and relatively small surface area of the lake allows this commonly seasonal phenomenon to persist, leading to a permanently stratified water column.

Stratification of lakes can lead to subsequent chemical stratification of redox-sensitive elements because of the redox activity of $\mathrm{mi}$ croorganisms. Measurements of physical parameters in Lake Matano reveal that it has a permanent pycnocline at $\sim 100 \mathrm{~m}$ depth stably separating the mixolimnion, the upper mixed water layer in contact with the atmosphere, from the monimolimnion, the deep anoxic waters. The redox or chemocline, marking the gradual chemical transition from completely oxygenated surface waters to increasingly reducing deep waters, extends from $\sim 100 \mathrm{~m}$ to $\sim 220 \mathrm{~m}$ depth (Crowe et al., 2008b).

The unique geochemistry of Lake Matano arises owing to the interplay between the geophysical characteristics of the environment and the activity of resident microbes in the lake. Spatiochemical stratification of electron acceptors is observed in the lake as follows: oxygen concentrations drop until they reach undetectable levels at $\sim 100 \mathrm{~m}$ depth. At this depth the dissolved $\mathrm{Mn}$ concentration increases to $10 \mu \mathrm{M}$ 
and of $\mathrm{Fe}(\mathrm{II})$ to $140 \mu \mathrm{M}$. Both $\mathrm{Fe}(\mathrm{II})$ and dissolved $\mathrm{Mn}$ concentrations do not drop dramatically from this concentration as the depth increases to $300 \mathrm{~m}$ (Crowe et al., 2008b). At the same time, the sulfate concentrations in Lake Matano remain very low $(<20 \mu \mathrm{M})$. Modeling studies predict that microbially mediated sulfate reduction is not expected to occur in the water column but rather in the sediment, whereas sulfide accumulation in the water column is limited to below detection by the low solubility of iron sulfide minerals and the high concentration of Fe(II) (Crowe et al., 2008b).

Spatiochemical stratification of various electron donors is intimately linked to microbial oxidation of organic matter. The autochthonous organic carbon from primary productivity in the lake is very low, and it is the degradation of allochthonous organic matter, accounting for most of the dissolved organic carbon, that likely leads to spatiochemical stratification. The dissolved organic carbon is mineralized completely between 100 and $200 \mathrm{~m}$ depth concomitant with the increase in Fe(II) concentrations, suggesting microbial $\mathrm{Fe}$ (III) reduction as a possible means of substrate oxidation (Crowe et al., 2008b). It is likely that an iron cycle operates across the chemocline with some flux of iron from the sediment to the water column. Modeling studies suggest that a combination of various phenomena might lead to the steady-state concentrations of $\mathrm{Fe}$ in this region. These include (i) the descent of insoluble $\mathrm{Fe}$ (III) hydroxides, (ii) the appearance of $\mathrm{Fe}$ (II) due to microbially mediated Fe(III) reduction, (iii) the diffusion of $\mathrm{Fe}$ (II) from

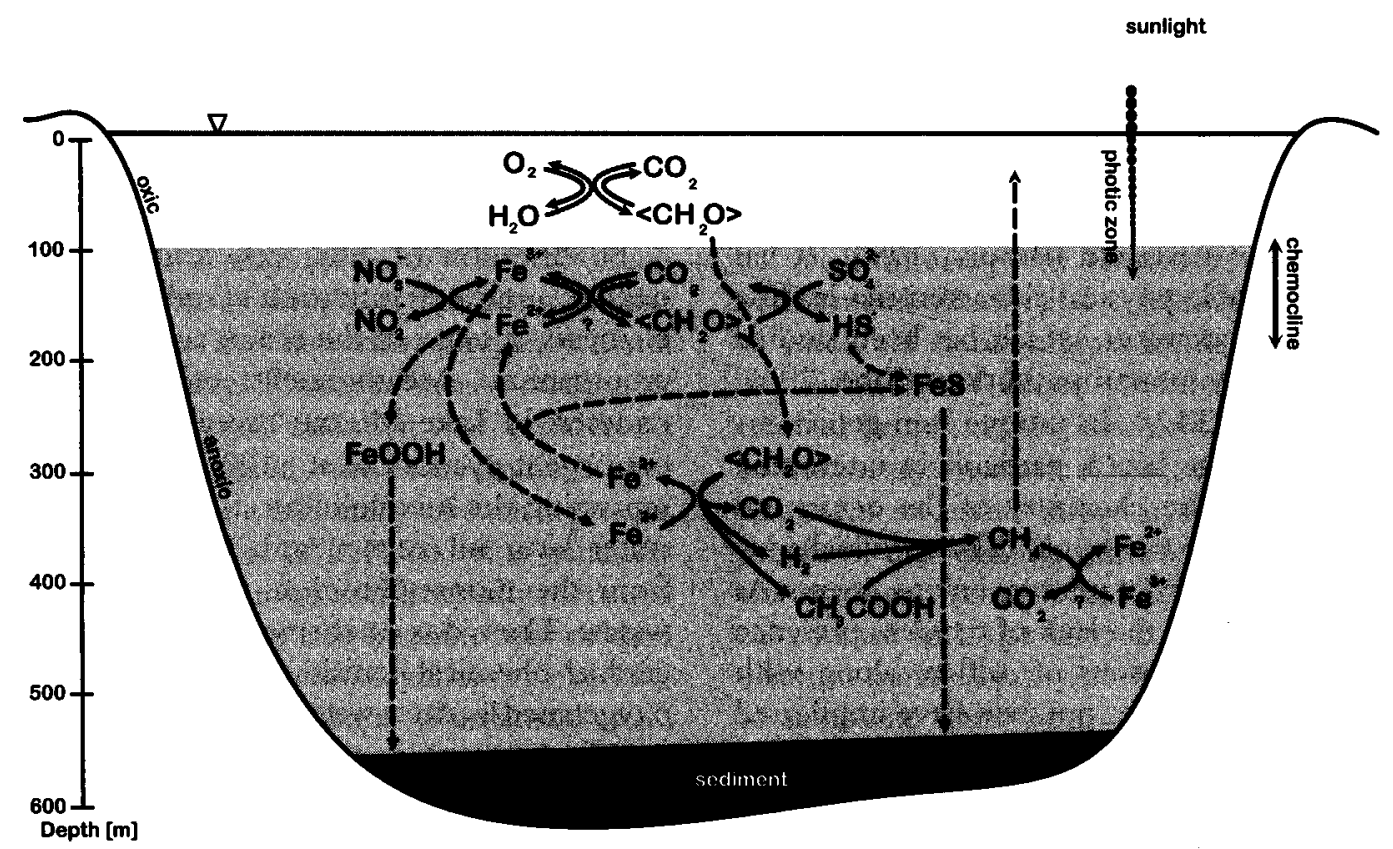

FIGURE 3 Simplified schematic illustrating the interactions of the iron cycle with other element cycles in Lake Matano. The oxic surface waters are shown with a white background, the anoxic monimolimion is shown in light grey. Penetration of sunlight and phototrophic transformations are indicated with dotted lines, nonphototrophic microbial transformations are indicated with solid lines, and precipitation and diffusion are shown by dashed lines. Coupled arrows, such as organic matter oxidation to carbon dioxide $\left(<\mathrm{CH}_{2} \mathrm{O}\right\rangle$ to $\left.\mathrm{CO}_{2}\right)$ with sulfate reduction to hydrogen sulfide $\left(\mathrm{SO}_{4}\right.$ to $\mathrm{HS}^{-}$), illustrate closely linked redox transformations. Several hypothesized, but still insufficiently investigated potential processes in Lake Matano, such as photoferrotrophy and iron-dependent anaerobic methane oxidation, are highlighted with a question mark. 
the monimolimnion, (iv) the regeneration of $\mathrm{Fe}$ (III) by $\mathrm{Fe}$ (II) oxidation at the redox boundary, and (v) the upward flux of soluble Fe(II) from the sediment to monimolimnion (Fig. 3) (Crowe et al., 2008b).

In the anoxic deep waters, once anaerobic microorganisms have utilized the more favorable electron acceptors, methanogenesis and anaerobic methane oxidation (AOM) can contribute to the carbon cycle. Sulfate reduction is more energetically favorable than methanogenesis, and sulfate-reducing bacteria outcompete methanogens for acetate as a carbon source (Capone and Kiene, 1988; Reeburgh, 2007). The absence of sulfate in the Lake Matano water column precludes this competition (Crowe et al., 2008b). However, the abundance of $\mathrm{Fe}$ and $\mathrm{Mn}$ introduces the possibility of microbes that reduce these minerals competing with methanogens for acetate. In addition, the absence of sulfate and nitrate in Lake Matano, the two well-established electron acceptors that are coupled to AOM, raises the possibility that $\mathrm{Fe}$ and $\mathrm{Mn}$ are more important players in $A O M$ in this environment (Crowe, 2008; Boetius et al., 2000; Raghoebarsing et al., 2006). The recent demonstration that marine sediments can couple anaerobic methane oxidation to $\mathrm{Fe}$ and $\mathrm{Mn}$ reduction shows that such reactions are feasible (Beal et al., 2009). Methane production occurs primarily in the sediment despite the presence of considerable amounts of $\mathrm{Fe}$ and $\mathrm{Mn}$. Disappearance of methane below the pycnocline between 100 and $200 \mathrm{~m}$ suggests likelihood of AOM in this zone (Crowe, 2008).

The concentrations of nitrogen and phosphorus are below detection limits in the mixolimnion. Ammonium is detected in the monimolimnion as the predominant $\mathrm{N}$ species, while soluble phosphate is the predominant $\mathrm{P}$ species across the chemocline (Crowe et al., 2008b). The appearance of soluble phosphate increases with the $\mathrm{Fe}$ (II) concentration suggesting that the $\mathrm{P}$ and $\mathrm{Fe}$ cycles are linked in this environment, probably involving sorption and removal of phosphate from the mixo- limnion by the particulate Fe(III) species. The lack of essential nutrients along with the high concentration of chromium [Cr(VI)] might account for the low primary productivity in the mixolimnion of Lake Matano (Crowe et al., 2008b).

Given the many spatiochemical gradients of common substrates for microbial metabolisms in Lake Matano, the likelihood of finding organisms that actively contribute to shaping these gradients is high. For example, photosynthetic pigment measurements in the lake have revealed that chlorophyll $a$ is present at low levels in the surface oxic layer where cyanobacteria would be commonly expected to contribute significantly to primary productivity in nutrient-richer environments. The low levels of light-absorbing pigments, such as chlorophyll $a$, in the surface layer allow light to penetrate to the deeper layers where bacteriochlorophyll $e$ predominates. This pigment is characteristic of anoxygenic photosynthetic bacteria that belong to the Chlorobiaceae that thrive under lower-light conditions. Consistently with this, 16S rDNA studies have indicated the presence of various members of this family in the redoxcline of Lake Matano (Crowe et al., 2008a). The high concentration of Fe(II) in this layer suggests that it might be serving as an electron donor for anoxygenic photosynthesis for these organisms and that their activities might influence iron cycling in the lake. However, whether this is, in fact, the case, or whether other $\mathrm{Fe}(\mathrm{II})$-oxidizing and $\mathrm{Fe}$ (III)-reducing organisms make greater contributions to the iron cycle is not clear. Indeed, it is possible that different groups of microorganisms control the iron biogeochemistry of the lake at different times, and that these microbial communities change altogether from year to year. Such depth of knowledge, ultimately, is necessary for being able to predict how microbial communities will respond to and, in turn, modify an environment like Lake Matano as it changes over time. How can we resolve this?

As described at the beginning of this chapter, a variety of traditional and molecular 
microbiological methods could be used to provide some insight and inform our understanding of the microbial communities and biogeochemical dynamics in this environment. Fortunately, recent work on Lake Matano has provided us with detailed information on the geochemistry of the lake (Crowe, 2008; Crowe et al., 2008a, 2008b), paving the road for some of the in situ techniques. Traditional light microscopy could be used to study microbial populations in the lake sediments and their spatial variability close to the chemocline (e.g., by the buried slide method). Because of low concentrations of microorganisms in the water column itself, however, more powerful techniques such as TEM and SEM could be necessary, which would provide the additional benefit of allowing investigation of the physical association of microorganisms with freshly formed minerals, such as iron (hydro)oxides from microbial iron oxidation. A reliable assessment of in situ geomicrobial activity via isotope labeling at the chemocline, in the case of phototrophic organisms, could be foiled by slow growth in the relatively low light at this depth; however, chemotrophic organisms could be operating on faster time scales if external carbon sources to the lake provide sufficient substrate for growth. While limited by slow growth, advanced isotope techniques such as RNA-SIP are of particular interest for an environment like Lake Matano, where a high degree of species endemism suggests the possible occurrence and likely importance of novel microorganisms and unique metabolic pathways that could be identified by this technique.

In vitro batch culture and chemostat studies of microorganisms from this environment are highly desirable to assess their metabolic potential but depend on enrichment and isolation of organisms from the water column. Slow growth might be a limiting factor in the ultimate success of this approach. Culture-independent techniques, however, could be used regardless, and FISH could be used, for example, to study the small-scale spatial distribution, abundance, and physical association of various bacterial and archaea groups identified by $16 \mathrm{~S}$ fingerprinting to be present in the lake sediments. Modern extensions of the approach, such as FISH-SIMS, could be similarly successful in investigating microbial populations in the lake, possibly aiding identification and study of a so-far elusive but suspected syntrophic community that combines anaerobic methane oxidation with metal reduction in this unique environment. Although technically and computationally challenging, the combination of metagenomic, -transcriptomic, and -proteomic techniques could significantly advance our understanding of the genetic metabolic potential, actively expressed metabolic pathways, and geochemically active enzymes the microbial communities in Lake Matano command. Detailed genetic studies of the organisms, however, would require reasonably fast-growing pure cultures, whose metabolic machinery for iron oxidation or reduction, for example, could then be assessed by random mutagenesis (for genetically tractable organisms) or heterologous complementation (for intractable strains with suitable tractable strains that are closely related). Once whole genomes of novel organisms from this environment would become available, bioinformatics provides powerful additional tools to search for metabolic key components that contribute to the biogeochemical cycling of iron and other elements in this environment, and whose identification is crucial for our understanding of the biogeochemical dynamics of this system.

\section{CONCLUSIONS}

We began this chapter with the assertion that a holy grail for environmental microbiologists is to understand the biogeochemistry of an environment sufficiently well to predict its behavior. This is a tall order and requires tremendous effort on the part of many groups to achieve for any given environment. One might reasonably ask if the complexity of real-world systems is so vast as to make this impossible to achieve? Perhaps, but we can hope that first-order predictions about the behavior of a given biogeochemical system are attainable, provided the dominant pathways are known and the controlling variables are well defined. 
In the case of the example we discussed in detail in this chapter, Lake Matano, although we know basic aspects about its geochemistry and microbial communities, much remains to be learned. We do not have a good appreciation for how the structure of its microbial community changes over time, or how changes to this structure affect the geochemical profiles of the lake. We do not understand which environmental variables control the success of particular members of the community, or how functionally redundant it is (e.g., particular organisms may come and go, but the geochemical reactions they catalyze might be similarly catalyzed by a different group of organisms). The better able we are to characterize these aspects, and to point to underlying molecular catalysts (e.g., metabolic enzymes), their rates, and the variables that regulate them, the better able we will be to make predictions about how the lake might respond to environmental perturbations.

Despite these knowledge gaps, the current state of research in microbe-metal interactions provides a fascinating outlook. From years of investigations in geochemistry and microbiology, we can appreciate the tremendous scope of possible pathways. We are working in a historically opportune moment, when enough is known about specific microbial processes to allow us to venture into assessing their relative contributions and importance to the complex cycling of iron and other elements in situ. The coevolution of microbial life and the environment is much akin to a terrific puzzle where we know enough of the pieces to get a first blurry glimpse of the magnificent full picture, but we do not know yet where each one goes nor how the pieces fit together. It will be satisfying to see the details of this picture emerge and sharpen over the coming years in a variety of systems.

\section{REFERENCES}

Adamczyk, J., M. Hesselsoe, N. Iversen, M. Horn, A. Lehner, P. H. Nielsen, M. Schloter, P. Roslev, and M. Wagner. 2003. The isotope array, a new tool that employs substrate-mediated labeling of rRNA for determination of microbial community structure and function. Appl. Environ. Microbiol. 69:6875-6887.

Allen, E. E., and J. F. Banfield. 2005. Community genomics in microbial ecology and evolution. Nat. Rev. Microbiol. 3:489-498.

Amann, R., and B. M. Fuchs. 2008. Single-cell identification in microbial communities by improved fluorescence in situ hybridization techniques. Nat. Rev. Microbiol. 6:339-348.

Amann, R. I., L. Krumholz, and D. A. Stahl. 1990. Fluorescent-oligonucleotide probing of whole cells for determinative, phylogenetic, and environmental studies in microbiology. $J$. Bacteriol. 172:762-770.

Amann, R. I., W. Ludwig, and K. H. Schleifer. 1995. Phylogenetic identification and in situ detection of individual microbial cells without cultivation. Microbiol. Mol. Biol. Rev. 59:143-169.

Anbar, A. D., and A. H. Knoll. 2002. Proterozoic ocean chemistry and evolution: a bioinorganic bridge? Science 297:1137-1142.

Baker, B. J., and J. F. Banfield. 2003. Microbial communities in acid mine drainage. FEMS Microbiol. Ecol. 44:139-152.

Baker, W. W., and J. F. Banfield. 1998. Zones of chemical and physical interaction at interfaces between microbial communities and minerals: a model. Geomicrobiol. J. 15:223-244.

Beal, E. J., C. H. House, and V. J. Orphan. 2009. Manganese- and iron-dependent marine methane oxidation. Science 325:184-187.

Beja, O., L. Aravind, E. V. Koonin, M. T. Suzuki, A. Hadd, L. P. Nguyen, S. B. Jovanovich, C. M. Gates, R. A. Feldman, J. L. Spudich, E. N. Spudich, and E. F. DeLong. 2000. Bacterial rhodopsin: evidence for a new type of phototrophy in the sea. Science 289:1902-1906.

Berner, R. A., and K. A. Maasch. 1996. Chemical weathering and controls on atmospheric $\mathrm{O}_{2}$ and $\mathrm{CO}_{2}$ : fundamental principles were enunciated by J. J. Ebelmen in 1845. Geochim. Cosmochim. Acta 60:1633-1637.

Beukes, N. J., and J. Gutzmer. 2008. Origin and paleoenvironmental significance of major iron formations at the Archean-Paleoproterozoic boundary, p. 5-47. In S. Hagemann, C. Rosiere, J. Gutzmer, and N. J. Beukes (ed.), Reviews in Economic Geology, vol. 15. Banded Iron Formation-Related High-Grade Iron Ore. Society of Economic Geologists, Denver, CO.

Boetius, A., K. Ravenschlag, C. J. Schubert, D. Rickert, F. Widdel, A. Gieseke, R. Amann, B. B. Jorgensen, U. Witte, and O. Pfannkuche. 2000 . A marine microbial consortium apparently mediating anaerobic oxidation of methane. Nature 407:623-626. 
Brock, T. D. 1978. Thermophilic Microorganisms and Life at High Temperatures. Springer-Verlag, New York, NY.

Brooks, J. L. 1950. Speciation in ancient lakes. Q. Rev. Biol. 25:131-176.

Burdige, D. J., and P. E. Kepkay. 1983. Determination of bacterial manganese oxidation rates in sediments using an in situ dialysis technique. I. Laboratory studies. Geochim. Cosmochim. Acta 47:1907-1916.

Canfield, D. E., K. S. Habicht and B. Thamdrup. 2000. The Archean sulfur cycle and the early history of atmospheric oxygen. Science 288:658-661.

Canfield, D. E., B. Thamdrup, and J. W. Hansen. 1993. The anaerobic degradation of organic matter in Danish coastal sediments: iron reduction, manganese reduction, and sulfate reduction. Geochim. Cosmochim. Acta 57:3867-3883.

Canfield, D. E., E. Kristensen, and B. Thamdrup. 2005. Aquatic Geomicrobiology. Elsevier, San Diego, CA.

Canfield, D. E., R. Raiswell, and S. Bottrell. 1992. The reactivity of sedimentary iron minerals toward sulfide. Am. J. Sci. 292:659-683.

Capone, D. G., and R. P. Kiene. 1988. Comparison of microbial dynamics in marine and fresh water sediments: contrasts in anaerobic carbon catabolism. Limnol. Oceanogr. 33:725-749.

Clement, B. G., L. E. Kehl, K. L. DeBord, and C. L. Kitts. 1998. Terminal restriction fragment patterns (TRFPs), a rapid, PCR-based method for the comparison of complex bacterial communities. J. Microbiol. Methods 31:135-142.

Cohan, F. M. 2002. What are bacterial species? Annu. Rev. Microbiol. 56:457-487.

Croal, L. R., Y. Jiao, and D. K. Newman. 2007. The fox operon from Rhodobacter strain SW2 promotes phototrophic $\mathrm{Fe}(\mathrm{II})$ oxidation in Rhodobacter capsulatus SB1003. J. Bacteriol. 189:1774-1782.

Crowe, S. A., S. Katsev, K. Leslie, A. Sturm, C. Magen, S. Nomosatryo, M. A. Pack, J. D. Kessler, W. S. Reeburgh, J. A. Roberts, L. Gonzáles, G. D. Haffner, A. Mucci, B. Sundby, and D. A. Fowle. 2010. The methane cycle in ferruginous Lake Matano. Geobiology 9(1):61-78. http:// dx.doi.org/10.1111/j.1472-4669.2010.00257.x.

Crowe, S. A., C. Jones, S. Katsev, C. Magen, A. H. O'Neill, A. Sturm, D. E. Canfield, G. D. Haffiner, A. Mucci, B. Sundby, and D. A. Fowle. 2008a. Photoferrotrophs thrive in an Archean Ocean analogue. Proc. Natl. Acad. Sci. USA 105:15938-15943.

Crowe, S. A., A. H. O'Neill, S. Katsev, P. Hehanussa, G. D. Haffner, B. Sundby, A. Mucci, and D. A. Fowle. 2008b. The biogeochemistry of tropical lakes: a case study from Lake Matano, Indonesia. Limnol. Oceanogr. 53:319-331.
Delsuc, F., H. Brinkmann, and H. Philippe. 2005. Phylogenomics and the reconstruction of the tree of life. Nat. Rev. Genet. 6:361-375.

Doolittle, W. F. 2000. Uprooting the tree of life. Sci. Am. 282:90-95.

Duan, Y., L. Zhou, D. G. Hall, W. Li, H. Doddapaneni, H. Lin, L. Liu, C. M. Vahling, D. W. Gabriel, K. P. Williams, A. Dickerman, Y. Sun, and T. Gottwald. 2009. Complete genome sequence of citrus huanglongbing bacterium, 'Candidatus Liberibacter asiaticus' obtained through metagenomics. Mol. Plant-Microbe Interact. 22:1011-1020.

Dumont, M. G., and J. C. Murrell. 2005. Stable isotope probing-linking microbial identity to function. Nat. Rev. Microbiol. 3:499-504.

Dunbar, J., L. O. Ticknor, and C. R. Kuske. 2001. Phylogenetic specificity and reproducibility and new method for analysis of terminal restriction fragment profiles of $16 \mathrm{~S}$ rRNA genes from bacterial communities. Appl. Environ. Microbiol. 67:190-197.

Edwards, K. J., P. L. Bond, T. M. Gihring, and J. F. Banfield. 2000. An archaeal iron-oxidizing extreme acidophile important in acid mine drainage. Science 287:1796-1799.

Edwards, K. J., B. M. Goebel, T. M. Rodgers, M. O. Schrenk, T. M. Gihring, M. M. Cardona, B. Hu, M. M. McGuire, R. J. Hamers, N. R. Pace, and J. F. Banfield. 1999. Geomicrobiology of pyrite (FeS2) dissolution: case study at Iron Mountain, California. Geomicrobiol. J. 16:155-179.

Ehrlich, H. L., and D. K. Newman. 2009a. Molecular methods in geomicrobiology, p. 139-156. In H. L. Ehrlich and D. K. Newman (ed.), Geomicrobiology. CRC Press, Boca Raton, FL.

Ehrlich, H. L., and D. K. Newman. 2009b. Nonmolecular methods in geomicrobiology, p. 117-138. In H. L. Ehrlich and D. K. Newman (ed.), Geomicrobiology. CRC Press, Boca Raton, FL.

Eilers, H., J. Pernthaler, F. O. Glockner, and R. Amann. 2000. Culturability and in situ abundance of pelagic bacteria from the North Sea. Appl. Environ. Microbiol. 66:3044-3051.

Emerson, D., and J. V. Weiss. 2004. Bacterial iron oxidation in circumneutral freshwater habitats: findings from the field and the laboratory. Geomicrobiol. J. 21:405-414.

Falkowski, P. G., R. T. Barber, and V. Smetacek. 1998. Biogeochemical controls and feedbacks on ocean primary production. Science 281:200206.

Fraústo da Silva, J. J. R., and R. J. P. Williams. 2001. The Biological Chemistry of the Elements: the Inorganic Chemistry of Life. Oxford University Press, New York, NY. 
Garrels, R. M., and A. Lerman. 1981. Phanerozoic cycles of sedimentary carbon and sulfur. Proc. Natl. Acad. Sci. USA 78:4652-4656.

Gentry, T. J., G. S. Wickham, C. W. Schadt, Z. He, and J. Zhou. 2006. Microarray applications in microbial ecology research. Microb. Ecol. 52:159-175.

Ghiorse, W. C., and D. L. Balkwill. 1983. Enumeration and morphological characterization of bacteria indigenous to subsurface environments. Dev. Ind. Microbiol. 24:213-224.

Giovannoni, S. J., E. F. Delong, G. J. Olsen, and N. R. Pace. 1988. Phylogenetic group-specific oligonucleotide probes for identification of single microbial cells. J. Bacteriol. 170:720-726.

Glass, J. B., F. Wolfe-Simon, and A. D. Anbar. 2009. Coevolution of metal availability and nitrogen assimilation in cyanobacteria and algae. Geobiology 7:100-123.

Guss, A. M., B. Mukhopadhyay, J. K. Zhang, and W. W. Metcalf. 2005. Genetic analysis of mch mutants in two Methanosarcina species demonstrates multiple roles for the methanopterindependent $\mathrm{C}-1$ oxidation/reduction pathway and differences in $\mathrm{H}_{2}$ metabolism between closely related species. Mol. Microbiol. 55:1671-1680.

Guyer, R. L., and D. E. Koshland, Jr. 1989. The molecule of the year. Science 246:1543-1546.

Herbert, D., R. Elsworth, and R. C. Telling. 1956. The continuous culture of bacteria; a theoretical and experimental study. J. Gen. Microbiol. 14:601-622

Hesselsoe, M., S. Fureder, M. Schloter, L. Bodrossy, N. Iversen, P. Roslev, P. H. Nielsen, M. Wagner, and A. Loy. 2009. Isotope array analysis of $R$ hodocyclales uncovers functional redundancy and versatility in an activated sludge. ISME J. 3:1349-1364.

Hoff, K. J., M. Tech, T. Lingner, R. Daniel, B. Morgenstern, and P. Meinicke. 2008. Gene prediction in metagenomic fragments: a large scale machine learning approach. BMC Bioinf. 9:217231.

Hughes, J. B., J. J. Hellmann, T. H. Ricketts, and B. J. Bohannan. 2001. Counting the uncountable: statistical approaches to estimating microbial diversity. Appl. Environ. Microbiol. 67:4399-4406.

Isley, A. E., and D. H. Abbott. 1999. Plumerelated mafic volcanism and the deposition of banded iron formations. J. Geophys. Res. Solid Earth 104:15461-15477.

Ivanov, M. V. 1968. Microbiological Processes in the Formation of Sulfur Deposits. U.S. Department of Agriculture and the National Science Foundation (Israel Program for Scientific Translations), Washington, DC.
Jannasch, H. W. 1967. Growth of marine bacteria at limiting concentration of organic carbon in seawater. Limnol. Oceanogr. 12:264-271.

Jannasch, H. W. 1969. Estimations of bacterial growth in natural waters. J. Bacteriol. 99:156-160.

Jannasch, H. W., and C. O. Wirsen. 1981. Morphological survey of microbial mats near deep-sea thermal vents. Appl. Environ. Microbiol. 41:528538.

Jargeat, P., C. Cosseau, B. Ola'h, A. Jauneau, P. Bonfante, J. Batut, and G. Becard. 2004. Isolation, free-living capacities, and genome structure of "Candidatus Glomeribacter gigasporarum," the endocellular bacterium of the mycorrhizal fungus Gigaspora margarita. J. Bacteriol. 186:6876-6884.

Kaeberlein, T., K. Lewis, and S. S. Epstein. 2002. Isolating "uncultivable" microorganisms in pure culture in a simulated natural environment. Science 296:1127-1129.

Kappler, A., C. Pasquero, K. O. Konhauser, and D. K. Newman. 2005. Deposition of banded iron formations by anoxygenic phototrophic $\mathrm{Fe}(\mathrm{II})$-oxidizing bacteria. Geology 33:865-868.

Kappler, A., and K. L. Straub. 2005. Geomicrobiological cycling of iron. Rev. Mineral. Geochem. 59:85-108.

Klaassens, E. S., W. M. de Vos, and E. E. Vaughan. 2007. Metaproteomics approach to study the functionality of the microbiota in the human infant gastrointestinal tract. Appl. Environ. Microbiol. 73:1388-1392.

Klappenbach, J. A., P. R. Saxman, J. R. Cole, and T. M. Schmidt. 2001. rrndb: the ribosomal RNA operon copy number database. Nucleic Acids Res. 29:181-184.

Konhauser, K. O., L. Amskold, S. V. Lalonde, N. R. Posth, A. Kappler, and A. D. Anbar. 2007. Decoupling photochemical Fe(II) oxidation from shallow-water BIF deposition. Earth Planet. Sci. Lett. 258:87-100.

Kraemer, S. 2004. Iron oxide dissolution and solubility in the presence of siderophores. Aquat. Sci. 66:3-18.

Kraemer, S. M., A. Butler, P. Borer, and J. Cervini-Silva. 2005. Siderophores and the dissolution of iron-bearing minerals in marine systems. Rev. Mineral. Geochem. 59:53-84.

Lawrence, J. R., D. R. Korber, G. M. Wolfaardt, and D. E. Caldwell. 1997. Analytical imaging and microscopy techniques. In C. J. Hurst, G. R. Knudsen, M. J. McInerney, L. D. Stetzenbach, and M. V. Walter (ed.), Manual of Environmental Microbiology. ASM Press, Washington, DC.

Lee, N., P. H. Nielsen, K. H. Andreasen, S. Juretschko, J. L. Nielsen, K. H. Schleifer, and M. Wagner. 1999. Combination of fluorescent in situ hybridization and microautoradiog- 
raphy-a new tool for structure-function analyses in microbial ecology. Appl. Environ. Microbiol. 65:1289-1297.

Liu, W. T., T. L. Marsh, H. Cheng, and L. J. Forney. 1997. Characterization of microbial diversity by determining terminal restriction fragment length polymorphisms of genes encoding $16 \mathrm{~S}$ rRNA. Appl. Environ. Microbiol. 63:4516-4522.

Lovley, D. R., D. E. Holmes, and K. P. Nevin. 2004. Dissimilatory $\mathrm{Fe}(\mathrm{III})$ and $\mathrm{Mn}$ (IV) reduction. Adv. Microb. Physiol. 49:219-286.

Luther, G. W., P. J. Brendel, B. L. Lewis, B. Sundby, L. Lefrancois, N. Silverberg, and D. B. Nuzzio. 1998. Simultaneous measurement of $\mathrm{O}_{2}, \mathrm{Mn}, \mathrm{Fe}, \mathrm{I}-$, and $\mathrm{S}(-\mathrm{II})$ in marine pore waters with a solid-state voltammetric microelectrode. Limnol. Oceanogr. 43:325-333.

Luther, G. W., B. T. Glazer, L. Hohmann, J. I. Popp, M. Taillefert, T. F. Rozan, P. J. Brendel, S. M. Theberge, and D. B. Nuzzio. 2001. Sulfur speciation monitored in situ with solid state gold amalgam voltammetric microelectrodes: polysulfides as a special case in sediments, microbial mats and hydrothermal vent waters. J. Environ. Monit. 3:61-66.

Maloy, S. R., and J. E. Cronan. 1994. Microbial Genetics. Jones and Bartlett Publishers, Sudbury, MA.

Maron, P. A., L. Ranjard, C. Mougel, and P. Lemanceau. 2007. Metaproteomics: a new approach for studying functional microbial ecology. Microb. Ecol. 53:486-493.

Martinez, A., A. S. Bradley, J. R. Waldbauer, R. E. Summons, and E. F. DeLong. 2007. Proteorhodopsin photosystem gene expression enables photophosphorylation in a heterologous host. Proc. Natl. Acad. Sci. USA 104:5590-5595.

McArthur, J. V. 2006. Microbial Ecology: An Evolutionary Approach. Academic Press, San Diego, CA.

Miller, F. D., and C. L. Hershberger. 1984. A quantitative beta-galactosidase alpha-complementation assay for fusion proteins containing human insulin B-chain peptides. Gene 29:247-250.

Morel, F. M. M. 2003. The biogeochemical cycles of trace metals in the oceans. Science 300:944-947.

Morgan, J. W., and E. Anders. 1980. Chemical composition of Earth, Venus, and Mercury. Proc. Natl. Acad. Sci. USA 77:6973-6977.

Muyzer, G., E. C. de Waal, and A. G. Uitterlinden. 1993. Profiling of complex microbial populations by denaturing gradient gel electrophoresis analysis of polymerase chain reaction-amplified genes coding for $16 \mathrm{~S}$ rRNA. Appl. Environ. Microbiol. 59:695-700.

Myers, N., R. A. Mittermeier, C. G. Mittermeier, G. A. da Fonseca, and J. Kent. 2000. Biodiversity hotspots for conservation priorities. Nature 403:853-858.
Novick, A. 1955. Growth of bacteria. Annu. Rev. Microbiol. 9:97-110.

Olsen, G. J., and C. R. Woese. 1993. Ribosomal RNA: a key to phylogeny. FASEB J. 7: 113-123.

Orphan, V. J., C. H. House, K. U. Hinrichs, K. D. McKeegan, and E. F. DeLong. 2001. Methane-consuming archaea revealed by directly coupled isotopic and phylogenetic analysis. Science 293:484-487.

Ottesen, E. A., J. W. Hong, S. R. Quake, and J. R. Leadbetter. 2006. Microfluidic digital PCR enables multigene analysis of individual environmental bacteria. Science 314:1464-1467.

Ouverney, C. C., and J. A. Fuhrman. 1999. Combined microautoradiography-16S rRNA probe technique for determination of radioisotope uptake by specific microbial cell types in situ. Appl. Environ. Microbiol. 65:1746-1752.

Pelletier, E., A. Kreimeyer, S. Bocs, Z. Rouy, G. Gyapay, R. Chouari, D. Riviere, A. Ganesan, P. Daegelen, A. Sghir, G. N. Cohen, C. Medigue, J. Weissenbach, and D. Le Paslier. 2008. "Candidatus Cloacamonas acidaminovorans": genome sequence reconstruction provides a first glimpse of a new bacterial division. $J$. Bacteriol. 190:2572-2579.

Perfil'ev, B. V., and D. R. Gabe. 1969. Capillary Methods for Studying Microorganisms. University of Toronto Press, Toronto, Canada.

Pernthaler, A., A. E. Dekas, C. T. Brown, S. K. Goffredi, T. Embaye, and V. J. Orphan. 2008. Diverse syntrophic partnerships from deepsea methane vents revealed by direct cell capture and metagenomics. Proc. Natl. Acad. Sci. USA 105:7052-7057.

Pernthaler, A., J. Pernthaler, and R. Amann. 2002. Fluorescence in situ hybridization and catalyzed reporter deposition for the identification of marine bacteria. Appl. Environ. Microbiol. 68: 3094-3101.

Petsch, S. T., K. J. Edwards, and T. I. Eglinton. 2003. Abundance, distribution and delta C13 analysis of microbial phospholipid-derived fatty acids in a black shale weathering profile. Org. Geochem. 34:731-743.

Philippe, H., and J. Laurent. 1998. How good are deep phylogenetic trees? Curr. Opin. Genet. Dev. 8:616-623.

Posth, N. R., F. Hegler, K. O. Konhauser, and A. Kappler. 2008. Alternating $\mathrm{Si}$ and Fe deposition caused by temperature fluctuations in Precambrian oceans. Nat. Geosci. 1:703-708.

Pritchett, M. A., J. K. Zhang, and W. W. Metcalf. 2004. Development of a markerless genetic exchange method for Methanosarcina acetivorans $\mathrm{C} 2 \mathrm{~A}$ and its use in construction of new genetic 
tools for methanogenic archaea. Appl. Environ. Microbiol. 70:1425-1433.

Radajewski, S., P. Ineson, N. R. Parekh, and J. C. Murrell. 2000. Stable-isotope probing as a tool in microbial ecology. Nature 403:646649.

Raghoebarsing, A. A., A. Pol, K. T. van de PasSchoonen, A. J. P. Smolders, K. F. Ettwig, W. I. C. Rijpstra, S. Schouten, J. S. S. Damste, H. J. M. Op den Camp, M. S. M. Jetten, and M. Strous. 2006. A microbial consortium couples anaerobic methane oxidation to denitrification. Nature 440:918-921.

Rankama, K., and T. Georg Sahama. 1950. Geochemistry. University of Chicago Press, Chicago, IL.

Rappe, M. S., S. A. Connon, K. L. Vergin, and S. J. Giovannoni. 2002. Cultivation of the ubiquitous SAR11 marine bacterioplankton clade. $\mathrm{Na}$ ture 418:630-633.

Reeburgh, W. S. 2007. Oceanic methane biogeochemistry. Chem. Rev. 107:486-513.

Riesenfeld, C. S., P. D. Schloss, and J. Handelsman. 2004. Metagenomics: genomic analysis of microbial communities. Annu. Rev. Genet. 38:525-552.

Rokas, A., and P. W. Holland. 2000. Rare genomic changes as a tool for phylogenetics. Trends Ecol. Evol. 15:454-459.

Rother, M., and W. W. Metcalf. 2005. Genetic technologies for Archaea. Curr. Opin. Microbiol. 8:745-751.

Sabo, E., D. Roy, P. B. Hamilton, P. E. Hehanussa, R. McNeely, and G. D. Haffner. 2008. The plankton community of Lake Matano: factors regulating plankton composition and relative abundance in an ancient, tropical lake of Indonesia. Hydrobiologia 615:225-235. http://dx.doi. org/10.1007/s10750-008-9560-4.

Saito, M. A., D. M. Sigman, and F. M. M. Morel. 2003. The bioinorganic chemistry of the ancient ocean: the co-evolution of cyanobacterial metal requirements and biogeochemical cycles at the Archean-Proterozoic boundary? Inorg. Chim. Acta 356:308-318.

Salyers, A. A., G. Bonheyo, and N. B. Shoemaker. 2000. Starting a new genetic system: lessons from bacteroides. Methods 20:35-46.

Schlegel, H. G. 1993. General Microbiology. Cambridge University Press, New York City, NY.

Seeber, F., and J. C. Boothroyd. 1996. Escherichia coli beta-galactosidase as an in vitro and in vivo reporter enzyme and stable transfection marker in the intracellular protozoan parasite Toxoplasma gondii. Gene 169:39-45.

Shi, Y., G. W. Tyson, and E. F. Delong. 2009. Metatranscriptomics reveals unique microbial small RNAs in the ocean's water column. Nature 459:266-269.

Sieburth, J. M. 1975. Microbial Seascapes. A Pictorial Essay on Marine Microorganism and Their Environments. University Park Press, Baltimore, MD.

Stackebrandt, E., and B. M. Goebel. 1994. A place for DNA : DNA reassociation and 16S rRNA sequence analysis in the present species definition in bacteriology. Int. J. Syst. Bacteriol. 44:846-849.

Stahl, D. A. 1997. Molecular approaches for the measurement of density, diversity and phylogeny, p. 102-114. In C. J. Hurst, G. R. Knudsen, M. J. McInerney, L. D. Stetzenbach, and M. V. Walter (ed.), Manual of Environmental Microbiolog\%. ASM Press, Washington, DC.

Staley, J. T. 2003. Speciation and bacterial phylospecies, p. 40-48. In A. T. Bull (ed.), Microbial Diversity and Bioprospecting. ASM Press, Washington, DC.

Staley, J. T., and A. Konopka. 1985. Measurement of in situ activities of nonphotosynthetic microorganisms in aquatic and terrestrial habitats. Annu. Rev. Microbiol. 39:321-346.

Stumm, W., and J. J. Morgan. 1995. Aquatic Chemistry: Chemical Equilibria and Rates in Natural Waters. Wiley, New York, NY.

Svensson, E., A. Skoog, and J. P. Amend. 2004. Concentration and distribution of dissolved amino acids in a shallow hydrothermal system, Vulcano Island (Italy). Org. Geochem. 35:1001-1014.

Tran-Nguyen, L. T., M. Kube, B. Schneider, R. Reinhardt, and K. S. Gibb. 2008. Comparative genome analysis of "Candidatus Phytoplasma australiense" (subgroup tuf-Australia I; rp-A) and "Ca. Phytoplasma asteris" strains OY-M and AY-WB. J. Bacteriol. 190:3979-3991.

Ussher, S. J., E. P. Achterberg, and P. J. Worsfold. 2004. Marine biogeochemistry of iron. Environ. Chem. 1:67-80.

Valdivia, R. H., B. P. Cormack, and S. Falkow. 2006. The uses of green fluorescent protein in prokaryotes. Methods Biochem. Anal. 47:163-178.

Ward, D. M., M. M. Bateson, R. Weller, and A. L. Ruffroberts. 1992. Ribosomal-RNA analysis of microorganisms as they occur in nature. $A d v$. Microb. Ecol. 12:219-286.

Ward, D. M., M. J. Ferris, S. C. Nold, and M. M. Bateson. 1998. A natural view of microbial biodiversity within hot spring cyanobacterial mat communities. Microbiol. Mol. Biol. Rev. 62:1353-1370.

Ward, D. M., R. Weller, and M. M. Bateson. 1990. 16S rRNA sequences reveal numerous uncultured microorganisms in a natural community. Nature 345:63-65.

Warnecke, F., and M. Hess. 2009. A perspective: metatranscriptomics as a tool for the discovery of novel biocatalysts. J. Biotechnol. 142:91-95. 
Weber, K. A., J. Pollock, K. A. Cole, S. M. O'Connor, L. A. Achenbach, and J. D. Coates. 2006. Anaerobic nitrate-dependent iron(II) bio-oxidation by a novel lithoautotrophic betaproteobacterium, strain 2002. Appl. Environ. Microbiol. 72:686-694.

Wernegreen, J. J., A. B. Lazarus, and P. H. Degnan. 2002. Small genome of Candidatus Blochmannia, the bacterial endosymbiont of Camponotus, implies irreversible specialization to an intracellular lifestyle. Microbiology 148:2551-2556.

White, D. 2000. The Physiology and Biochemistry of Prokaryotes. Oxford Unversity Press, New York, NY.

Whiteley, A. S., M. Manefield, and T. Lueders. 2006. Unlocking the 'microbial black box' using RNA-based stable isotope probing technologies. Curr. Opin. Biotechnol. 17:67-71.

Widdel, F., S. Schnell, S. Heising, A. Ehrenreich, B. Assmus, and B. Schink. 1993. Ferrous iron oxidation by anoxygenic phototrophic bacteria. Nature 362:834-836.

Wilmes, P., and P. L. Bond. 2006. Metaproteomics: studying functional gene expression in microbial ecosystems. Trends Microbiol. 14:92-97.
Wilmes, P., S. L. Simmons, V. J. Denef, and J. F. Banfield. 2009. The dynamic genetic repertoire of microbial communities. FEMS Microbiol. Rev. 33:109-132.

Wilmes, P., M. Wexler, and P. L. Bond. 2008. Metaproteomics provides functional insight into activated sludge wastewater treatment. PLoS One 3:e1778.

Woyke, T., G. Xie, A. Copeland, J. M. Gonzalez, C. Han, H. Kiss, J. H. Saw, P. Senin, C. Yang, S. Chatterji, J. F. Cheng, J. A. Eisen, M. E. Sieracki, and R. Stepanauskas. 2009. Assembling the marine metagenome, one cell at a time. PLoS One 4:e5299.

Wu, L. Y., X. Liu, C. W. Schadt, and J. Z. Zhou. 2006. Microarray-based analysis of subnanogram quantities of microbial community DNAs by using whole-community genome amplification. Appl. Environ. Microbiol. 72:49314941.

Zengler, K., G. Toledo, M. Rappe, J. Elkins, E. J. Mathur, J. M. Short, and M. Keller. 2002. Cultivating the uncultured. Proc. Natl. Acad. Sci. USA 99:15681-15686. 